From such observations standards of normality for diet and performance in growth, reproduction and duration of life have been set up. We look forward to hear from our speakers today how far the search for similar standards for man has progressed.

\title{
The indices of nutritional change in Great Britain
}

By W. T. C. Berry, Ministry of Health, Alexander Fleming House, Elephant and Castle, London, S.E.I, and

Dorothy F. Hollingsworth, Ministry of Agriculture, Fisheries and Food, London, S.W.I

\section{Nature of the indices}

We have applied the term 'indices of nutritional change' to the various statistical returns that may be used to reveal slow changes occurring through an entire country.

The indices that we find most useful are:

(I) Food Consumption Levels in the United Kingdom published annually in the Board of Trade Journal.

(2) The National Food Survey.

(3) The stillbirth and neonatal death rates.

(4) Records of growth.

(5) The rejection rate of women volunteering for blood donation for the first time.

(6) The death rate from arteriosclerotic heart disease.

The first (see, for example, Ministry of Agriculture, Fisheries and Food, I962) shows the amounts of foods available per person at the retail stage of distribution. It takes no account of distribution within the community, or of waste beyond the retail level. The second (e.g. Ministry of Agriculture, Fisheries and Food: National Food Survey Committee, I 962) is a record of food entering the household, and is thus one stage nearer the consumer. The results are regularly available in relation to income of the head of the household, family size and geographical region. The National Food Survey does not record sweets purchased, or soft or alcoholic drinks, or certain other items liable to be bought by members of the family other than the housewife. Both sets of data are evaluated in nutritional terms, and in the National Food Survey average 'intakes' are compared with average 'requirements' based on the recommended allowances of the British Medical Association (r950). Neither index provides information on intakes of individuals.

The significance of the stillbirth and neonatal death rates has been thoroughly discussed by Duncan, Baird \& Thomson (1952). The rates do not, of course, reflect nutritional changes only.

The growth rate of schoolchildren is a valuable index. Boyne, Aitken \& Leitch (1957) wrote 'we think that more use might be made of the measurements made as a routine in schools,' and in fact the Ministry of Health had anticipated their recommendation by arranging some years before with the Ministry of Education that data 
should be collated from the annual returns of school medical officers in fourteen areas where at the time of school medical examination, at entrance and at leaving, heights and weights are tabulated; and in addition there are the 5-yearly surveys of the London County Council. We regard changes in height as more important today than changes in weight except in so far as the latter may indicate increasing fatness.

Acceleration or retardation of growth need not necessarily reflect changes in nutrition only; nevertheless, malnutrition, if it occurs, is likely to be reflected in a check in the acceleration of growth rate. Some have suggested that accelerated growth may not be beneficial, in that, for example, it may shorten life. Although this is not the place to discuss this point in detail, in our view too little attention is paid to the work of Slonaker (I93 I $a-e$, I935, I938), which is much more relevant to the problem than the oft-quoted studies on calorie restriction and longevity. Briefly, Slonaker set out to determine the optimum level of protein in the diet of rats, using a number of criteria such as growth rate, mature length, reproductive performance, the amount of voluntary exercise taken and the duration of life. He showed that up to a certain level of protein in the diet the rats showed improvements in health as judged by all these criteria. Above that level growth continued to increase, but no other measure of well-being. It may be, therefore, that accelerated growth in man is beneficial only so long as it is associated with increased well-being, a state which unfortunately defies quantification. If so, the assumption that rapid growth in British schoolchildren is still desirable is only justified by the impression that the best-grown groups of the community are still those most full of well-being. The incidence of obesity, one departure from well-being, may be capable of quantification. For example, a team trained by Dr J. M. Tanner measured the skinfold thicknesses of children whose heights and weights were recorded by London County Council in 1959 (Scott, r96r).

The index of anaemia in would-be blood donors has been so recently developed that its value as an indicator of nutritional change is still uncertain. The National Blood Transfusion Service rejects any volunteer with a haemoglobin value of less than $12.6 \mathrm{~g} / 100 \mathrm{ml}$, and records the numbers of new female volunteers who are accepted or rejected on this count. Would-be donors are an unrepresentative sample of the community because people who know they are anaemic may not volunteer. Nevertheless, some very anaemic women, presumably unaware of their anaemia, do volunteer, and we think that an increase in anaemia in women in general would be revealed by this index. For the past 3 years the rejection rate has been steady at between 6 and $7 \%$ with some variation between transfusion centres. Future trends will be watched.

The last index, the incidence of reported deaths from coronary disease and analogous conditions, must be regarded cautiously. As pointed out by Heasman \& Wilson ( 1959), changes in the age composition of the community, in the accuracy of diagnosis and in the amount of over-reporting by doctors all affect the reported incidence. Nevertheless, there is general agreement that some increase in deaths from arteriosclerotic heart disease has in fact occurred. The possibility that the increase may have 22 (I) 5 
a nutritional cause is still a matter for debate, but the increase is a warning against the assumption that the nutritional situation is solely one of progressive improvement.

There are thus not many indices. Yet in Britain we probably know more than is known elsewhere about the nutrition of our population. Many other sources of information have been found unsuitable. Infant mortality, maternal mortality and death rates from tuberculosis are too much affected by non-nutritional changes. Records from the school health service of the incidence of children showing unsatisfactory general condition-or in Scotland 'bad' or 'slightly defective' nutritionhave shown progressive decline to $0.68 \%$ in England and Wales, and $1.7 \%$ in Scotland, but though this decline is in accord with the acceleration of growth that has occurred the subjective nature of the assessment makes it unsuitable as an index. (Incidentally, the different percentages north and south of the Border may well reflect different standards only). Nevertheless, when malnutrition occurs in schoolchildren it does commonly take the form of an almost indefinable falling off in general condition which the older clinicians called 'poor nutritional state'.

The causes of dental caries are as yet too uncertain for caries to be utilized in an index.

\section{Relationship between indices}

In relating the indices of food consumption, perinatal mortality rate, and growth rate, two phases can be distinguished. The first was one of major improvements in all the indices, particularly during the war compared with before it. The second was one of relatively small fluctuations which were dependent largely on increased availability of foods, not all of them of high nutrient content. It is of interest to observe to what extent the various indices have changed in harmony during this second phase, because it might give an indication of whether the diet had been adequate for all sections of the community.

Records of food supply. The most striking change in the pattern of British food supplies during the last 80 years has been the reduction in the quantities of starchy foods, grain and potatoes, which accounted for over half the total calorie value of the national diet in 1880 but for only $30 \%$ in 1960 . There have been compensating increases in consumption of sugar and fats. Consumption of dairy products increased during the war and up to recent times, accounting for $9 \%$ of the total calories before the war and $12 \%$ in 1960 , while calories supplied by grain products decreased from 30 to $25 \%$ of the total. There has also been a considerable change in the distribution of foods within the community as will be seen in Table $\mathbf{I}$, which shows the range of calories and certain nutrients as a percentage of the mean intake, before and after the war.

Before the war the total supply of protein (used here as an index of the quality of the diet) amounted to $73 \mathrm{~g} /$ head day, which provided $9.6 \%$ of the total calorie supply. These quantities increased to $90 \mathrm{~g}$ and $12.0 \%$ respectively by 1945 . Thereafter total consumption of protein declined to about $82 \mathrm{~g}$ for the years from 1952 to 1955 and provided a minimum of $10.3 \%$ of the total calories in 1954 . From 1956 onwards protein consumption rose again to $85.6 \mathrm{~g} /$ head in 1960 , which supplied $10.9 \%$ of the total calories. 
Table 1. Range between the richest and poorest groups of the UK population as a percentage of the mean nutrient intake for all the groups

\begin{tabular}{|c|c|c|c|c|}
\hline & $\begin{array}{c}1936-7^{*} \\
\text { Calculated from } \\
\text { Crawford } \&\end{array}$ & $195^{*}$ & I $960 \dagger$ & $196 \mathrm{I} \dagger$ \\
\hline Nutrient & Broadley (1938) & \multicolumn{3}{|c|}{ National Food Survey } \\
\hline Calories & 40 & I I & 3 & 2 \\
\hline Protein & 44 & I 3 & 6 & 5 \\
\hline Calcium & 88 & 20 & 10 & IO \\
\hline Iron & 47 & I8 & 8 & Io \\
\hline Vitamin A & $8 I$ & 34 & I7 & I6 \\
\hline Thiamine & 71 & 9 & 5 & 6 \\
\hline Vitamin C & I 3 & 42 & $3 \mathrm{I}$ & 32 \\
\hline
\end{tabular}

(The poorest groups always consumed less)

\footnotetext{
* Ministry of Food: National Food Survey Committee (I952).

$\dagger$ Calculated from unpublished National Food Survey data for 1 st and $4^{\text {th }}$ quarter of the years to conform with the dates of the Crawford \& Broadley survey.
}

In summary, during the war the overall protein content of the diet increased and food was more equitably distributed. In the postwar period there was a fall in protein consumption to a trough around 1954 with some recovery by 1960 , albeit never to wartime levels.

Perinatal deaths. In accord with the improvement in supply and distribution of food during the war there was the well-known fall in stillbirths and neonatal deaths which was followed after the war by a steadier state. However, both stillbirth and the early neonatal death rates showed a slight rise in 195 I and 1954 in England and Wales, and thereafter declined again to new low levels of 19.8 stillbirths per 1000 total births and 13.3 neonatal (under I week) deaths per 1000 live births in I 960 . We would stress that changes of a non-nutritional nature may be presumed to be responsible certainly for a part of the fall in perinatal deaths, and that at the time when the check occurred in perinatal deaths there was considerable pressure on the maternity services due to the postwar 'bulge' in births; changes occurred too in the administration of maternity services. In 1955, on the other hand, the Ministry of Health circularized all establishments in charge of substantial maternity units, calling for concerted action against, particularly, maternal toxaemia, and this action was followed by a reduction in perinatal deaths. Nevertheless there was an adverse change in perinatal mortality when the level of protein in the diet fell, followed by an improvement in the perinatal death rate.

Growth rate of children. That children at a given age are taller and heavier than their forbears is common knowledge. Two questions of interest are when the process of acceleration will end, and whether there have been any checks in growth rate corresponding with the period of deterioration shown in the other indices.

To answer the first question some estimate has to be made of the full potential for growth of British children. Leitch \& Boyne (I960) have published records of groups of public-school boys in which the full potential appears to have been realized; but the trouble is that most of the data relate to ages at which many Stateschool children have left school. However Leitch \& Boyne's data do show that at 
Eton there was little change in height between 1937 and 1957 , and the records include ages $\mathrm{I}_{3}$ and $\mathrm{I}_{4}$. The London County Council reports also give averages for ages $13 \frac{1}{2}$ and $14 \frac{1}{2}$. Whereas Eton boys at age I $3 \frac{1}{2}$ may, from Leitch \& Boyne's data, be presumed to have averaged about 63 in. both in 1937 and 1957 , the London County Council boys aged I $3 \frac{1}{2}$ averaged only $5^{6.3}$ in. in $1908-9$, but by $193^{8}$ they averaged $58.7 \mathrm{in.}$ (Menzies, I 940), by 1949 they averaged $60 \mathrm{in}$. (Daley, r $95^{\circ}$ ) and by 1959,6 r 3 in. (Scott, I961). Similarly Leitch \& Boyne's data suggest that Etonians at $14 \frac{1}{2}$ averaged $65-65 \frac{1}{2}$ in.; in 1949 London County Council boys aged $14 \frac{1}{2}$ years averaged only 62.5 in. (Daley, 1950) but by 1959 they averaged 64.5 in. (Scott, I961). Even with the reservations with which records of this type have to be interpreted, it is obvious that the average height of the London County Council boys is approaching that of the Eton boys, and there is no evidence to suggest that it will not eventually equal it.

The London County Council records, being compiled at 5-yearly or longer intervals, do not tell us whether any fluctuations occurred in the first half of the

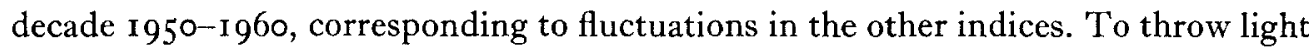
on this, Table 2 shows the unweighted average heights for boys and girls aged 5 and I4 from fourteen areas in England for each year from 1949 to 1960 (Ministry of Education, unpublished records).

Table 2. Unweighted mean heights (in.) of boys and girls aged 5 and $\mathrm{I}_{4}$ years from fourteen areas of England for the years 1949 to 1960 (Ministry of Education, unpublished records)

\begin{tabular}{|c|c|c|c|c|}
\hline \multirow[b]{2}{*}{ Year } & \multicolumn{2}{|c|}{ Aged 5 years } & \multicolumn{2}{|c|}{ Aged 14 years } \\
\hline & Boys & Girls & Boys & Girls \\
\hline I949 & $43 \cdot 1$ & $42 \cdot 7$ & $61 \cdot 6$ & $6 \pi \cdot 8$ \\
\hline $195^{\circ}$ & $43 \cdot 1$ & $42 \cdot 8$ & $62 \cdot 0$ & $61 \cdot 5$ \\
\hline 1951 & $43 \cdot 0$ & $42 \cdot 6$ & $61 \cdot 7$ & $6 \mathrm{I} \cdot 3$ \\
\hline 1952 & $43 \cdot I$ & $42 \cdot 5$ & $61 \cdot 9$ & $6 r \cdot 3$ \\
\hline I 953 & $43 \cdot 3$ & $42 \cdot 8$ & $62 \cdot I$ & $6 I \cdot 5$ \\
\hline 1954 & $43 \cdot I$ & $42 \cdot 7$ & $62 \cdot 1$ & $6 \mathrm{I} \cdot 5$ \\
\hline 1955 & $43 \cdot 4$ & $42 \cdot 9$ & $62 \cdot 2$ & $6 \pi \cdot 3$ \\
\hline 1956 & $43 \cdot 2$ & $42 \cdot 7$ & $62 \cdot 0$ & $6 r \cdot 3$ \\
\hline 1957 & $43 \cdot 2$ & $42 \cdot 8$ & $62 \cdot 4$ & 61.6 \\
\hline $195^{8}$ & $43 \cdot I$ & $42 \cdot 8$ & 62.6 & $61 \cdot 9$ \\
\hline 1959 & $43 \cdot 3$ & 42.8 & $62 \cdot 8$ & $6 \pi \cdot 6$ \\
\hline 1960 & $43 \cdot 2$ & $42 \cdot 9$ & $62 \cdot 9$ & $61 \cdot 8$ \\
\hline
\end{tabular}

In children of both ages, heights were slightly greater in 1960 than in 1949 , and for the children aged I4 the increase was most noticeable in the late I950s when the protein quality of the diet improved. The points at which the perinatal deaths rose in $195^{1}$ and 1954 are to some degree mirrored in small checks to growth.

\section{Identification of groups at risk}

As shown in the preceding section there is some measure of harmony between the various indices. It does not necessarily mean that there is (or was, in the early 1950 ) a section of the community that was suboptimally nourished, but it does not exclude that possibility, and the problem is to identify the section of the community least 
likely to be adequately nourished. Some of the material on which the indices are based has on occasion been analysed in detail, and when it has been done the groups which appeared most likely to be at risk were, as might be expected, among the poor and those with many children. One example is the finding of Heady \& Heasman (I959) that the social-class gradient of stillbirth and neonatal death rate persisted even when correction had been made for age and parity of mother. Another is in the many reports of lesser average stature in low-income groups and in large families, shown to exist in England by Yudkin (1944) and Bransby, Burn, Magee \& MacKecknie (1946) and in Scotland in 1947 by the Scottish Council for Research in Education: Mental Survey Committee (1953), and shown also by the most recent London County Council report on heights and weights (Scott, I 96I) and by current records of only children and children with three or more siblings in England (see Table 3).

Table 3. Mean height (in.) of boys of school or preschool age in England with no siblings or with three or more

(From school medical reports for 1961)

\begin{tabular}{clcc} 
Mean age & \multicolumn{1}{c}{ Place } & No siblings & $\begin{array}{c}\text { Three or } \\
\text { more siblings }\end{array}$ \\
5 years 6.I months & Croydon & $43 \cdot 8$ & $43 \cdot 1$ \\
& Salford & $43 \cdot 9$ & $42 \cdot 1$ \\
& Exeter & $43 \cdot 6$ & $42 \cdot 3$ \\
& York & $43 \cdot 4$ & $42 \cdot 7$ \\
& Sheffield & $43 \cdot 8$ & $42 \cdot 1$ \\
& Southampton & $43 \cdot 7$ & $42 \cdot 6$ \\
& Lancashire & $44 \cdot 4$ & $42 \cdot 7$ \\
& Nottinghamshire & $44 \cdot 3$ & $43 \cdot 6$ \\
Northumberland & $43 \cdot 6$ & $43 \cdot 4$ \\
& Gloucester & $44 \cdot 0$ & $43 \cdot 3$ \\
& Croydon & $64 \cdot 9$ & $63 \cdot 5$ \\
& Salford & $62 \cdot 8$ & $59 \cdot 8$ \\
& Exeter & $65 \cdot 4$ & $62 \cdot 7$ \\
& York & $64 \cdot 3$ & $62 \cdot 7$ \\
& Sheffield & $64 \cdot 1$ & $65 \cdot 7$ \\
& Southampton & $63 \cdot 9$ & $62 \cdot 1$ \\
& Lancashire & $65 \cdot 0$ & $63 \cdot 0$ \\
& Nottinghamshire & $64 \cdot 1$ & $62 \cdot 9$ \\
& Northumberland & $65 \cdot 1$ & $62 \cdot 8$ \\
& Gloucester & $64 \cdot 5$ & $63 \cdot 9$ \\
& Cumberland & $63 \cdot 6$ & $61 \cdot 2$
\end{tabular}

Similarly, in Table 4, National Food Survey results for 1960 (Ministry of Agriculture, Fisheries and Food: National Food Survey Committee, 1962) are analysed in terms of income of head of household (indicated as Classes A, B, and C and DI) and of family composition.

The first part of Table 4 shows that there is little change in the percentage of calories derived from protein in the diet, with increase in family size, despite the theoretically higher requirements of children, as indicated by the comparison with the recommended allowances of the British Medical Association's (1950) Committee 
Table 4. Protein in the diets of families of different composition within social classes

\begin{tabular}{|c|c|c|c|c|c|}
\hline \multirow[b]{2}{*}{ Class } & \multirow{2}{*}{$\begin{array}{l}\text { Households of } \\
\text { two adults, } \\
\text { both under } 55\end{array}$} & \multicolumn{4}{|c|}{$\begin{array}{l}\text { Households with one man and one woman } \\
\text { and the following number of children }\end{array}$} \\
\hline & & T & 2 & 3 & 4 or more \\
\hline \multicolumn{6}{|c|}{ Protein calories as percentage of total calories* } \\
\hline A & $12 \cdot 3$ & I $11 \cdot 7$ & I $1 \cdot 6$ & II $\cdot 6$ & $(\mathrm{II} \cdot \mathrm{I})$ \\
\hline B & $11 \cdot 4$ & $11 \cdot 3$ & II 14 & $I I \cdot 3$ & II $\cdot 0$ \\
\hline \multicolumn{6}{|c|}{$\begin{array}{c}\text { Protein intake as percentage of recommended allowance of the British } \\
\text { Medical Association's Committee on Nutrition (1950) }+\end{array}$} \\
\hline A & 136 & 113 & 102 & 93 & $(87)$ \\
\hline B & 122 & Io9 & 100 & 93 & 86 \\
\hline $\mathrm{C}$ and $\mathrm{D}_{\mathrm{I}}$ & 117 & 104 & 97 & 90 & 82 \\
\hline
\end{tabular}

Figures in parentheses are based on a sample of only sixteen households.

* Calculated from results in $\dagger$.

$\uparrow$ From Ministry of Agriculture, Fisheries and Food: National Food Survey Committee (1962).

on Nutrition. The comparison made in the second part, of course, begs the question as to how nearly the recommended allowances correspond to requirements.

\section{Conclusion}

The indices of nutritional change have been used here to test the bypothesis that a section of the community may still be suboptimally nourished, and this possibility has not been wholly excluded. They have been used also to show, within their limits, which section of the community is least likely to be adequately nourished. To test the hypothesis further it would be necessary to make use of other methods.

\section{REFERENCES}

Boyne, A. W., Aitken, F. C. \& Leitch, 1. (1957). Nutr. Abstr. Rev. 27, 1.

Bransby, E. R., Burn, J. L., Magee, H. E. \& Mackecknie, D. M. (1946). Brit. med.7. ii, 767.

British Medical Association (1950). Report of the Committee on Nutrition. London: British Medical Association.

Crawford, W. \& Broadley, H. (1938). The People's Food. London: Heinemann.

Daley, A. (1950). Report on the Heights and Weights of School Pupils in the County of London in 1949. London County Council Report no. 3692.

Duncan, E. L., Baird, D. \& Thomson, A. M. (1952). F. Obstet. Gynaec., Brit. Emp., 59, 183.

Heady, A. \& Heasman, M. A. (1959). Social and Biological Factors in Infant Mortality, p. I4. I.ondon: H.M. Stationery Office.

Heasman, M. A. \& Wilson, J. M. G. (1959). Mon. Bull. Minist. Hlth Lab. Serv. 18, 94.

Leitch, I. \& Boyne, A. W. (1960). Nutr. Abstr. Rev. 30, 1173.

Menzies, F. (1940). Report by the School Medical Officer (London County Council) on the Average Heights and Weights of Elementary School Children in the County of London in I938. Report no. 3464. London: P. S. King and Son Ltd.

Ministry of Agriculture, Fisheries and Food (r962). Bd Trade \%. 183, i.

Ministry of Agriculture, Fisheries and Food: National Food Survey Committee (1962). Domestic Food Consumption and Expenditure, I960. London: H.M. Stationery Office.

Ministry of Food: National Food Survey Committee (1952). Domestic Food Consumption and Expenditure, 1950. London: H.M. Stationery Office.

Scott, J. A. (I96I). Report on the Heights and Weights (and other Measurements) of School Pupils in the County of London in I959. London County Council Report no. 4086.

Scottish Council for Research in Education: Mental Survey Committee (1953). Social Implications of the 1977 Scottish Mental Survey. Publ. no. xxxv. London University Press. 
Slonaker, J. R. (1931a). Amer. F.Physiol. 96, 547.

Slonaker, J. R. (r93rb). Amer. F. Physiol. 97, 322.

Slonaker, J. R. (1931c). Amer. F. Physiol. 97, 573.

Slonaker, J. R. (193Id). Amer. F. Physiol. 97, 626

Slonaker, J. R. (r93re). Amer. F. Physiol. 98, 266.

Slonaker, J. R. (1935). Amer. F. Physiol. 1r3, 59.

Slonaker, J. R. (1938). Amer. F. Physiol. 123, 526.

Yudkin, J. (I944). Lancet, 247, 384 .

\section{Nutritional status, maternal physique and reproductive efficiency}

\section{By A. M. Thomson and W. Z. Billewicz, Obstetric Medicine Research Unit (Medical Research Council), University of Aberdeen}

Some time ago, the obstetricians in Aberdeen classified primigravidae, at their first attendance at an antenatal clinic, according to their general clinical appearance. Those who were in poor physical condition often had the appearance of being illnourished, though lesions indicative of specific deficiency states were almost never seen. In due course we correlated the clinical assessments with the subsequent obstetric histories. Table I gives some of the results; the rates of prematurity (birth weight $2500 \mathrm{~g}$ or less), Caesarean section and perinatal death were much higher among women originally thought to be in poor general condition than in those thought to be in good condition.

Table I. Incidence of obstetric abnormalities in Aberdeen primigravidae by maternal health and physique as assessed at the first antenatal examination. Twin pregnancies have been excluded

\begin{tabular}{|c|c|c|c|c|}
\hline & \multicolumn{4}{|c|}{ Health and physique } \\
\hline & Very good & Good & Fair & Poor; very poor \\
\hline Prematurity* $(\%)$ & $5 \cdot I$ & $6 \cdot 4$ & 10.4 & $12 \cdot I$ \\
\hline Caesarean section $(\%)$ & $2 \cdot 7$ & $3 \cdot 5$ & $4 \cdot 2$ & $5 \cdot 4$ \\
\hline Perinatal deaths & & & & \\
\hline per rooo births & $26 \cdot 9$ & $29 \cdot 2$ & $44 \cdot 8$ & 62.8 \\
\hline No, of subjects & 707 & 2088 & 1294 & 223 \\
\hline Percentage tall & & & & \\
\hline$(5 \mathrm{ft} 4$ in. or more $)$ & 42 & 29 & 18 & I3 \\
\hline $\begin{array}{l}\text { Percentage short } \\
\text { (under } 5 \mathrm{ft} \mathrm{x} \text { in.) }\end{array}$ & 10 & 20 & 30 & 48 \\
\hline
\end{tabular}

The lower part of Table I shows that women in poor condition were often shorter than those in good condition. A possible explanation is that many short women had been poorly nourished during growth, and became stunted as well as generally unhealthy adults. Conversely, tall women had mostly been well-nourished during growth, and became healthy adults who reached the full stature of which they were genetically capable. Some support for the hypothesis that many short individuals are stunted rather than genetically short was provided by Bernard (r952). He showed that in groups of short women and men antero-posterior flattening of the pelvic brim, resembling that found in the rachitic pelvis but less in degree, was common, 